\title{
Study of Character Association and Path Analysis in Indian mustard (Brassica juncea L.) Genotypes
}

\author{
Sudheer Singh $^{1}$, Ashutosh ${ }^{2 *}$, Ajeet Kumar Dwivedi ${ }^{1}$, Omesh Kumar ${ }^{2}$, \\ K. Kumar ${ }^{1}$ and O. P. Verma ${ }^{1}$ \\ ${ }^{1}$ Department of Genetics and Plant Breeding, Narendra Deva University of Agriculture and \\ Technology, Kumarganj, Faizabad (U. P), India \\ ${ }^{2}$ Department of Genetics and Plant Breeding, Institute of Agricultural Sciences, Banaras \\ Hindu University, Varanasi (U.P.), India \\ *Corresponding author
}

\begin{abstract}
A B S T R A C T
Path coefficient analysis with correlation coefficient for yield and its element were conducted at analysis Farm Department of Genetics \& Plant Breeding, Narendra Deva

Keywords

Correlation, Path analysis, Indian mustard

\section{Article Info}

Accepted:

25 January 2020

Available Online:

10 February 2020

University of Agriculture and Technology, Faizabad (U.P.) throughout Rabi, 2011-12, on sixty four genotypes with four checks varieties (Vardan, Ashirwad, Kranti, and Maya) in Augmented Block Design. Information obtained by this method helps in direct and indirect selection for genetic improvement of yield. Results revealed that the seed yield plant ${ }^{-1}$ showed extremely vital and positive correlational statistics with length of main flower cluster, secondary branches plant ${ }^{-1}$, primary branches plant ${ }^{-1}$, plant height and siliquae on main flower cluster whereas non-significant positive correlation with remaining characters. Path analysis disclosed that characters viz., seed yield exhibited the highest positive direct impact on length of main flower cluster followed by primary branches plant ${ }^{-1}$, secondary branches plant ${ }^{-1}$ and plant height. Considering each, the correlation co-efficients and path co-efficients along, length of main flower cluster, number of primary \& secondary branches plant $^{-1}$ and plant height emerged as vital elements of seed yield which should be given due importance during indirect selection criteria.
\end{abstract}

\section{Introduction}

Indian mustard [Brassica juncea (L.) Czern \& Coss] is one among the foremost necessary oilseed crops of the country and it occupies significantly massive acerage among the Brassica group of oil seed crops. It is the second most important edible oilseed crop after soybean in the country. It contains adequate quantity of the 2 essential fatty acids, linoleic and linolenic which are not present in many of the other edible oils. At World level, rapeseed-mustard crops area unit full-grown in fifty three countries spreading over the six continents, covering a region of 22.33 million hectare with on average production of 33.17 million tonnes and an mean yield of 1468 $\mathrm{kg} /$ hectare ranging from $333 \mathrm{~kg} /$ hectare (Tazikistan) to $6667 \mathrm{~kg} /$ hectare (Algeria). India stands second in both acreage and 
production of rapeseed and mustard in Asia. The crops are cultivated on an area of 5.76 million ha with a net production of 6.79 million tonnes, and an average yield of 1184 kg/ha (Anonymous, 2015-16). Per capita consumption of edible oil is likely to reach 23$43 \mathrm{~kg}$ by 2030 from the present level of 13.4 $\mathrm{kg}$. In India, it is predominantly cultivated in Rajasthan, U.P., M.P., Haryana, Gujarat, West Bengal, Assam and Bihar states.

In recent years, the country produced lesser than that of our national requirement. This gap is increasing day by day as the breeding approaches for Indian mustard improvement continued confined to selection and recombination followed by selection. Even supposing there are varieties with high yield potential, yet there is wide fluctuation in area, production and productivity which is mainly attributed due to its cultivation on marginal lands either rain fed or with limited irrigation facilities and non-availability of biotic and abiotic stress-resistant/tolerant varieties for various mustard growing regions of the country. Achievement of any crop improvement programme for developing a high yielding cultivar lies within the nature and magnitude of variation for various yield components.

Thus, character association studies become a necessity for initiating a successful breeding programme. Yield is a complex quantitative trait which is subject to environmental fluctuations requiring indirect selection of simply highly heritable traits for its improvement. This is possible through estimates of correlations which help in determining the degree to which various yield contributing characters are associated (Wright, 1921). Path analysis (Dewey and Lu, 1959) further reveal the association of these characters with yield are due to direct impact on yield or may be a consequence of their indirect effects via. Other component characters. It can discriminate between the realistic (genetic effects) and inflated (environmental effects) correlation. Some information related to these is known, but correlation coefficients vary from material to material. Keeping in view the above aspects, the present investigation was undertaken to review the correlation and path analysis for the development of high yielding cultivar of Indian mustard adapted to this region for the advantage of the farmers.

\section{Materials and Methods}

The experiment was conducted to evaluate the sixty four germplasm of Indian mustard including elite lines and land races with four popular checks viz., Vardan, Ashirwad, Kranti, and Maya, well adopted varieties of the region. These genotypes exhibiting wide spectrum of variation for various agronomical and morphological characters, were obtained from the germplasm maintained at Oilseed section of Genetics and Plant Breeding Department. These lines were grown in single row plot of 5 meter length. Each block consisted of 10 entries plus 4 checks. The spacing between row to row and plant to plant was $30 \mathrm{~cm}$ and $15 \mathrm{~cm}$ maintained by thinning. On the basis of five randomly selected plants, data were recorded on days to maturity, plant height, primary and secondary branches plant ${ }^{1}$, length of main flower cluster, number of siliquae on main flower cluster, number of seeds siliqua ${ }^{-1}$, seed yield plant $^{-1}, 1000$-seed weight, oil content (\%) except days to $50 \%$ flowering which was recorded on plot basis.

Data recorded on eleven quantitative traits of Indian mustard genotypes were subjected to statistical analysis, correlation co-efficient were calculated as per the methods suggested by Wright (1921) and path analysis suggested by Dewey and Lu (1959) were used to partition the correlation coefficient in to direct and indirect effects. 


\section{Results and Discussion}

A wide spectrum of variability was observed for all the characters under study indicating that there is ample scope for effective selection based on the correlated and noncorrelated response. Seed yield or economic yield in most the crops is referred as super character which results from the multiplicative interactions of many alternative characters which are termed as yield elements. Thus, identification of important yield elements and knowledge regarding their association with seed yield and also with each other is very useful for selecting efficient genotypes for evolving high yielding varieties. In this respect, the coefficient of correlation that provides symmetrical activity of degree of association between 2 variables or characters, facilitate in understanding the nature and magnitude of association among yield and yield elements.

The genotypic correlation coefficients between different characters were generally similar in sign and nature to the corresponding phenotypic correlation coefficients. However, in general genotypic correlation coefficient were higher in magnitude from the corresponding phenotypic values. Similar results have been reported by Sirohi et al., (2004).

The phenotypic co-efficient amongst the eleven traits including seed yield under the present investigation is presented in Table 1. Seed yield plant ${ }^{-1}$ exhibited highly significant and positive correlation with length of main flower cluster (0.520), secondary branches plant $^{-1}(0.485)$, primary branches plant $^{-1}$ (0.418), plant height (0.387) and siliquae on main flower cluster (0.328). The nonsignificant positive correlation with seeds siliqua $^{-1}(0.218)$, days to maturity (0.166), 1000 -seed weight (0.126) and oil content (0.105).
However, seed yield plant ${ }^{-1}$, days to $50 \%$ flowering, 1000-seed weight showed strong and positive association with days to maturity and length of main flower cluster. 1000-seed weight showed strong and negative association with primary branches plant ${ }^{-1}$ and secondary branches plant $^{-1}$. Plant height, primary branches plant ${ }^{-1}$, secondary branches plant $^{-1}$, days to maturity and length of main flower cluster showed positive association with siliquae on main flower cluster.

Earlier reports in mustard have also indicated existence of strong association of seed yield plant $^{-1}$ with primary branches plant $^{-1}$, secondary branches plant $^{-1}$, plant height, length of main flower cluster and siliquae on main flower cluster (Sandhu and Gupta 1996, Thakral et al., 1997, Khulbe and Pant 1999, Verma et al., 2001, Pant et al., 2002, Srivastava and Singh 2002, Singh et al., (2003), Ramanjaneyulu and Giri (2007), Verma et al., (2008) and Singh and Singh (2010).

The estimates of correlation coefficient, although, indicate inter-relationship of different traits, but it does not furnish information on cause and effect. Under such situation path analysis helps the breeder to identify the index of selection. Path analysis emerged as a powerful and widely used technique for understanding the direct and indirect contribution of yield contributing traits.

In this study, the path coefficient analysis was carried out using estimates of simple correlation coefficients among 11 characters presented in Table- 2 revealed that length of main flower cluster (0.488) showed maximum direct effect followed by primary branches plant $^{-1}(0.3320)$, secondary branches plant ${ }^{-2}$ (0.3253) and plant height (0.2635) demonstrated highly positive direct contribution to seed yield plant ${ }^{-1}$. 
Table.1 Estimates of correlation coefficient among 11 characters in mustard genotypes

\begin{tabular}{|c|c|c|c|c|c|c|c|c|c|c|c|c|}
\hline S. No & Characters & $\begin{array}{c}\text { Days to } \\
\mathbf{5 0 \%} \\
\text { flowering }\end{array}$ & $\begin{array}{l}\text { Days to } \\
\text { maturity }\end{array}$ & $\begin{array}{c}\text { Plant } \\
\text { height }(\mathrm{cm})\end{array}$ & $\begin{array}{c}\text { Primary } \\
\text { branches/ } \\
\text { plant }\end{array}$ & $\begin{array}{c}\text { Secondary } \\
\text { branches/ } \\
\text { plant }\end{array}$ & $\begin{array}{c}\text { Length of } \\
\text { main } \\
\text { flower } \\
\text { cluster } \\
\text { (cm) }\end{array}$ & $\begin{array}{c}\text { Siliquae } \\
\text { on main } \\
\text { flower } \\
\text { cluster }\end{array}$ & $\begin{array}{l}\text { Seeds/ } \\
\text { siliqua }\end{array}$ & $\begin{array}{l}\text { 1000-seed } \\
\text { weight }(g)\end{array}$ & $\begin{array}{c}\text { Oil } \\
\text { content } \\
(\%)\end{array}$ & $\begin{array}{l}\text { Seed yield/ } \\
\text { plant }(g)\end{array}$ \\
\hline 1. & Days to $50 \%$ flowering & 1.000 & $0.458 * *$ & $0.352 * *$ & -0.028 & $-0.278^{*}$ & $-0.284 *$ & 0.199 & 0.031 & -0.125 & 0.032 & $-0.278^{*}$ \\
\hline 2. & Days to maturity & & 1.000 & $0.578 * *$ & -0.066 & $-0.295^{*}$ & $0.270^{*}$ & $0.324 * *$ & 0.039 & $0.295^{*}$ & 0.099 & 0.166 \\
\hline 3. & Plant height $(\mathrm{cm})$ & & & 1.000 & $0.408 * *$ & 0.124 & $0.289 *$ & $0.666 * *$ & 0.058 & 0.042 & -0.042 & $0.387 * *$ \\
\hline 4. & Primary branches/ plant & & & & 1.000 & $0.601 * *$ & -0.124 & $0.338 * *$ & 0.036 & $-0.278 *$ & -0.110 & $0.417 * *$ \\
\hline 5. & Secondary branches/ plant & & & & & 1.000 & 0.113 & $0.251 *$ & 0.024 & $-0.316^{*}$ & -0.098 & $0.485^{* *}$ \\
\hline 6. & $\begin{array}{l}\text { Length of main flower cluster } \\
(\mathrm{cm})\end{array}$ & & & & & & 1.000 & $0.478 * *$ & 0.072 & $0.250^{*}$ & 0.101 & $0.520 * *$ \\
\hline 7. & Siliquae on main flower cluster & & & & & & & 1.000 & 0.071 & -0.013 & 0.174 & $0.328 * *$ \\
\hline 8. & Seeds/ siliqua & & & & & & & & 1.0000 & 0.064 & -0.063 & 0.218 \\
\hline 9. & 1000 -seed weight $(\mathrm{g})$ & & & & & & & & & 1.000 & 0.128 & 0.126 \\
\hline 10. & Oil content $(\%)$ & & & & & & & & & & 1.000 & 0.105 \\
\hline 11. & Seed yield/ plant $(\mathrm{g})$ & & & & & & & & & & & 1.0000 \\
\hline
\end{tabular}

* Significant at 5 per cent probability level, ** Significant at 1 per cent probability level

Table.2 Direct and indirect effects of 11 characters on seed yield per plant in mustard genotypes

\begin{tabular}{|c|c|c|c|c|c|c|c|c|c|c|c|c|}
\hline S. No & Characters & $\begin{array}{l}\text { Days to } \\
50 \% \\
\text { flowering }\end{array}$ & $\begin{array}{l}\text { Days to } \\
\text { maturity }\end{array}$ & $\begin{array}{l}\text { Plant } \\
\text { height } \\
(\mathrm{cm})\end{array}$ & $\begin{array}{l}\text { Primary } \\
\text { branches/ } \\
\text { plant }\end{array}$ & $\begin{array}{c}\text { Secondary } \\
\text { branches/ } \\
\text { plant }\end{array}$ & $\begin{array}{l}\text { Length of } \\
\text { main flower } \\
\text { cluster }(\mathrm{cm})\end{array}$ & $\begin{array}{l}\text { Siliquae on } \\
\text { main flower } \\
\text { cluster }\end{array}$ & $\begin{array}{l}\text { Seeds/ } \\
\text { siliqua }\end{array}$ & $\begin{array}{l}1000 \text {-seed } \\
\text { weight }(\mathrm{g})\end{array}$ & $\begin{array}{c}\text { Oil } \\
\text { content } \\
(\%)\end{array}$ & $\begin{array}{c}\text { Seed } \\
\text { yield/ } \\
\text { plant(g) }\end{array}$ \\
\hline 1. & Days to $50 \%$ flowering & -0.1131 & 0.0471 & 0.0928 & -0.0091 & -0.0903 & -0.1384 & -0.0652 & 0.0055 & -0.0132 & 0.0059 & $-0.278^{*}$ \\
\hline 2. & Days to maturity & -0.0518 & 0.1029 & 0.1522 & -0.0218 & -0.0961 & 0.1316 & -0.1065 & 0.0068 & 0.0309 & 0.0180 & 0.1663 \\
\hline 3. & Plant height $(\mathrm{cm})$ & -0.0398 & 0.0595 & 0.2635 & 0.1353 & 0.0402 & 0.1410 & -0.2188 & 0.0090 & 0.0044 & -0.0078 & $0.387 * *$ \\
\hline 4. & Primary branches/ plant & 0.0031 & -0.0068 & 0.1074 & 0.3320 & 0.1956 & -0.0603 & -0.1109 & 0.0063 & -0.0292 & -0.0201 & $0.417 * *$ \\
\hline 5. & Secondary branches/ plant & 0.0314 & -0.0304 & 0.0326 & 0.1996 & 0.3253 & 0.0554 & -0.0824 & 0.0042 & -0.0331 & -0.0179 & $0.485 * *$ \\
\hline 6. & $\begin{array}{l}\text { Length of main flower } \\
\text { cluster }(\mathrm{cm})\end{array}$ & 0.0321 & 0.0278 & 0.0762 & -0.0410 & 0.0369 & 0.4880 & -0.1570 & 0.0128 & 0.0262 & 0.0184 & $0.520 * *$ \\
\hline 7. & $\begin{array}{l}\text { Siliquae on main flower } \\
\text { cluster }\end{array}$ & -0.0225 & 0.0334 & 0.1756 & 0.1122 & 0.0817 & 0.2333 & -0.3284 & 0.0126 & -0.0014 & 0.0319 & $0.328 * *$ \\
\hline 8. & Seeds/ siliqua & -0.0035 & 0.0040 & 0.0134 & 0.0118 & 0.0077 & 0.0353 & -0.0233 & 0.1772 & 0.0067 & -0.0114 & 0.2179 \\
\hline 9. & 1000 -seed weight $(\mathrm{g})$ & 0.0142 & 0.0303 & 0.0110 & -0.0922 & -0.1027 & 0.1218 & 0.0042 & 0.0113 & 0.1050 & 0.0234 & 0.1264 \\
\hline 10. & Oil content $(\%)$ & -0.0037 & 0.0101 & -0.0112 & -0.0364 & -0.0318 & 0.0491 & -0.0572 & -0.0111 & 0.0134 & 0.1832 & 0.1046 \\
\hline
\end{tabular}


Therefore, considering these traits as selection criteria will be advantageous in bringing improvement in Indian mustard. These results are in conformity with the findings of Shalini et al., (2000), Pandey and Singh (2005), and Verma et al., (2008). However, other characters contributing substantially positive direct effect on seed yield; oil content $(0.183)$ followed by seed per siliqua (0.177), 1000seed weight (0.105) and days to maturity (0.103). The negative and substantial direct effects on seed yield plant ${ }^{-1}$ were exerted by days to $50 \%$ flowering (-0.113) and silque on main flower cluster $(-0.328)$. The remaining characters have little and non-significant effect and thus indicating their negligible direct contributions towards seed yield. The estimate of residual factor (0.580) was negligible which reflects that majority of the yield contributing traits have been included in the study.

Plant height, siliquae on main flower cluster, primary branches plant ${ }^{-1}$, secondary branches plant $^{-1}$, length of main flower cluster and seeds siliqua $^{-1}$ exerted high order positive indirect effects on seed yield plant ${ }^{-1}$. Other characters exhibited substantial positive effects via some other characters. The occurrence of negative as well as positive indirect effects on yield by one or another character presents a complex situation where a compromise balance is required to attain proper balance for different yield components for determining ideotype of seed yield per plant in mustard. The result of path analysis obtained under present study are also in close agreement with the result of Sandhu and Gupta 1996, Patel et al., 2001, Pant et al., 2002, Mehak et al., 2003, Bikram Singh 2004, Sudan et al., 2004.

Considering correlation and path co-efficients together, it can be concluded that the characters length of main flower cluster, number of primary and secondary branches plant $^{-1}$ and plant height were the important yield contributing characters and should be given due importance during selection as these characters had positive direct effects on seed yield and had significant positive association with seed yield.

\section{References}

Dewey, D.R. and Lu, K.H. 1959. A correlation and path coefficient analysis of components of crested wheat grass seed production. Agron. J., 51: 515-518.

Khulbe, R.K. and Pant, D.P. 1999. Correlation and path coefficient analysis of yield and its components in Indian mustard. Crop Res., 17(3): 371-375.

Pandey, S. and Singh, B. 2005. Inter character association and path analysis in Indian mustard [Brassica juncea (L.) Czern. \& Coss.]. Adv. Pl. Sci., 18: 511-514.

Pant, S.C. and Singh, P. 2001. Genetic variability in Indian mustard. Agric. Sci. Digest., 21(1): 28-30.

Pant, S.C., Singh, P., Kumar, R., Sanjiv, M. and Singh, S.P. 2002.Correlation and path analysis in Indian mustard. $P l$. Arch., 2(2): 207-211.

Ramanjaneyulu, A.V. and Giri, G. 2007. Correlation and path coefficient analysis in Indian mustard [Brassica juncea (L.) Czern \& Coss.]. J. Res. ANGRAU., 35: 107-110.

Sandhu, S.K. and Gupta, N.P. 1996. Genetic divergence and correlation studies in Indian mustard. Crop Improv, 23(2): 253-256.

Shalini, T.S., Sheriff, R., Kulkarni, R.S. and Venkataramana, P. 2000. Correlation and pathanalysis of Indian mustard germplasm. Mysore J. Agril. Sci., 1: 226-229.

Singh, B. 2004. Character association and path analysis under dryland condition in Indian mustard (B. juncea). Cruciferae Newslett., 25: 99-100. 
Singh, M., Srivastava, R.L., Lalta, P. and Dixit, R.K. 2003.Correlation and path analysis in Indian mustard [Brassica juncea (L.) Czern \& Coss.]. Adv. Pl. Sci., 16(1): 311-315.

Singh, M., Srivastava, R.L., Prasad, L. and Dixit, R.K. 2003. Correlation and path analysis in Indian mustard [Brassica juncea (L.) Czern \& Coss]. Adv Plant Sci., 16: 311-315.

Singh, S.K. and Singh, A.K. 2010. Interrelationship and path analysis for seed yield in Indian mustard. Indian Journal of Ecology, 37: 8-12.

Sirohi, S.P.S., Sanjai, M. and Kumar, A. 2004.Correlation and path analysis of Indian mustard [Brassica juncea (L.) Czern \& Coss.]. Ann. Agric. Res., 25(4): 491-494.

Srivastava, M.K. and Singh, B.P. 2002. Correlation and path analysis in Indian mustard [Brassica juncea (L.) Czern \& Coss.]. Crop Res., 23(3): 517-521.
Sudan, R.S., Singh, S.P. and Kashyap, S.C. 2004. Path analysis of yield and its components in Indian mustard [Brassica juncea (L.) Czern \& Coss.]. Ann. Agric. Bio. Res., 9(2): 119-122.

Thakral, N.K., Kumar, P. and Yadava, T.P. 1997. Character association in Ethiopian mustard under normal and saline environments. Cruciferae Newslet., 19: 95-96.

Verma, O.P., Bhajan, R. and Singh, H.P. 2001. Association among seedling and yield contributing traits in mustard. Curciferae Newslet., 23: 49-50.

Verma, R., Sharma, R. and Sharma, S.K. 2008. Association studies among yield and its component characters in Indian mustard [Brassica juncea (L.) Czern \& Coss.]. Indian J. Genet. Plant Breed, 68: 87-89.

Wright, S. 1921. Correlation and causation. J. Agric. Res., 20: 557-585.

\section{How to cite this article:}

Sudheer Singh, Ashutosh, Ajeet Kumar Dwivedi, Omesh Kumar, K. Kumar and Verma O. P. 2020. Study of Character Association and Path Analysis in Indian mustard (Brassica juncea L.) Genotypes. Int.J.Curr.Microbiol.App.Sci. 9(02): 3218-3223. doi: https://doi.org/10.20546/ijcmas.2020.902.362 